\title{
Ernst-Wolfgang Böckenförde and the Politics of Constituent Power
}

Lars Vinx, Department of Philosophy

Bilkent University

vinx@bilkent.edu.tr

+903122903136

Acknowledgments: The author would like to thank Mirjam Künkler and Tine Stein for their kind invitation to the workshop on Ernst-Wolfgang Böckenförde's constitutional theory in Munich in 2016, as well as for their helpful comments on a draft of this paper. I am likewise indebted for valuable feedback to Christoph Schönberger, David Dyzenhaus, Joseph Almog, and the anonymous reviewer for Jurisprudence. The initial work on this paper was undertaken during a sabbatical from Bilkent University which I spent in the Department of Philosophy at the University of Turku. I would like to thank Bilkent University for the opportunity to take a sabbatical, and the friends in Turku for their great hospitality.

\section{Introduction}

The concept of constituent power has become increasingly central to democratic constitutional theory in recent years. A full realization of the promise of democracy, many authors argue, requires more than just a democratic organization of the constituted political system. To be fully democratic, and thus to be fully legitimate, a constitution must also have 
been made by the people, or at least be under the control of the people as a power standing outside the constitution. ${ }^{1}$

Though theorizing on constituent power has a long historical pedigree, ${ }^{2}$ the contemporary debate is often taking its cues from the constitutional theory of Carl Schmitt, despite the fact that Schmitt's relationship to democracy was rather ambiguous. ${ }^{3}$ While some authors regard Schmitt's constitutional theory as a welcome antidote to the supposedly excessive and unduly elitist constitutionalism of contemporary liberal democracies, ${ }^{4}$ others have argued that it was little more than an attempt to provide a pseudo-democratic cloak for an executive-centered

\footnotetext{
${ }^{1}$ Recent defenses of the constitutional-theoretic relevance of the notion of constituent power include: Andreas Kalyvas, 'Popular Sovereignty, Democracy, and the Constituent Power' (2005) 12 Constellations 223; Hans Lindahl, 'Constituent Power and Reflexive Identity: Towards an Ontology of Collective Selfhood' in Martin Louglin and Neil Walker (eds), The Paradox of Constitutionalism: Constituent Power and Constitutional Form (OUP 2007); Andreas Kalyvas, Democracy and the Politics of the Extraordinary. Max Weber, Carl Schmitt, and Hannah Arendt (CUP 2008); Martin Loughlin, Foundations of Public Law (OUP 2010) 209-237; Paul Kahn, Political Theology. Four New Chapters on the Concept of Sovereignty (Columbia University Press 2012); Joel I. Colon-Rios, Weak Constitutionalism. Democratic Legitimacy and the Question of Constituent Power (Routledge 2012); Martin Loughlin, 'The Concept of Constituent Power' (2014) 13 European Journal of Political Theory 218; Dieter Grimm, Sovereignty: The Origin and Future of a Political Concept (Columbia University Press 2015); Hans Lindahl, 'Constituent Power and the Constitution' in David Dyzenhaus (ed), Philosophical Foundations of Constitutional Law (OUP 2016).

${ }^{2}$ See Egon Zweig, Die Lehre vom Pouvoir Constituant. Ein Beitrag zum Staatsrecht der französischen Revolution (J.C.B Mohr/Paul Siebeck 1909); Richard Bourke and Quentin Skinner (eds), Popular Sovereignty in Historical Perspective (CUP 2016); Daniel Lee, Popular Sovereignty in Early Modern Constitutional Thought (OUP 2016); Andrew Arato, The Adventures of the Constituent Power. Beyond Revolutions? (Cambridge University Press 2017) 45-182.

${ }^{3}$ This applies to all authors cited in $\mathrm{n} 1$.

${ }^{4}$ See for instance Colon-Rios, Weak Constitutionalism (n 1); Kalyvas, Democracy and the Politics of the Extraordinary (n1).
} 
authoritarianism. ${ }^{5}$ Schmitt's association with national socialism, of course, lends prima facie support to the latter view. It is at the very least open to question whether it is wise to invoke Schmitt as the patron saint of a truly democratic theory of constituent power.

There can be little doubt, on the other hand, that Schmitt was a creative and innovative constitutional thinker who addressed issues that are undertheorized in mainstream liberal constitutional theory. Reliance on Schmitt's ideas should not be rejected on the basis of guilt by association with Nazism. At the end of the day, what matters is whether sufficiently careful and selective adaptations of Schmitt's arguments can turn out to be fruitful in the context of democratic constitutional theory. This paper will offer a critical discussion of the most important attempt to develop a theory of constituent power inspired by Schmitt: ErnstWolfgang Böckenförde's seminal article on constituent power as a liminal concept of constitutional law, which has recently been made available in English translation. ${ }^{6}$

Böckenförde is one of postwar Germany's pre-eminent public lawyers and constitutional theorists. He served with distinction on the German constitutional court and his democratic credentials are beyond all doubt. ${ }^{7}$ I propose that Böckenförde's theory of constituent power

\footnotetext{
${ }^{5}$ See Renato Cristi, 'Schmitt on Constituent Power and the Monarchical Principle' (2011) 18 Constellations 352; David Dyzenhaus, Legality and Legitimacy: Carl Schmitt, Hans Kelsen, and Hermann Heller in Weimar (OUP 1997) 38-101; William E. Scheuerman, Carl Schmitt: The End of Law (Rowman\&Littlefield 1999); Ingeborg Mauss, Bürgerliche Rechtstheorie und Faschismus. Zur sozialen Funktion und aktuellen Wirkung der Theorie Carl Schmitts (Wilhelm Fink Verlag, 1976).

${ }^{6}$ Ernst-Wolfgang Böckenförde, 'The Constituent Power of the People: A Liminal Concept of Constitutional Law' in Ernst-Wolfgang Böckenförde, Constitutional and Political Theory. Selected Writings (Mirjam Künkler and Tine Stein eds, OUP 2017).

${ }^{7}$ See for Böckenförde's thought and career Mirjam Künkler and Tine Stein, 'State, Law, and Constitution: Ernst-Wolfgang Böckenförde's Political and Legal Thought in Context' in Böckenförde, Constitutional and Political Theory (n 6).
} 
can be treated as a test case for deciding whether attempts to build a democratic theory of constituent power on Schmittian grounds are promising or not. It is unlikely that any such attempt will lead to satisfactory results if Böckenförde's careful and illuminating adaptation of Schmitt's approach to constituent power turns out to be indefensible. ${ }^{8}$ This paper will argue that this is indeed the case. Böckenförde's theory of constituent power falls short of offering a satisfactory account of constitutional legitimacy for reasons that have to do with its indebtedness to Schmitt.

Let me briefly explain why this result has more than mere exegetical significance. The general claim that a constitution's legitimacy depends on production by constituent power can obviously be developed in a number of rather different ways. According to one common view inspired by Hannah Arendt, a process of constitution-making that deserves to be recognized as an authentic exercise of democratic constituent power would be characterized by maximal inclusiveness, careful deliberation on matters of constitutional principle, and a high degree of consensus-orientation. ${ }^{9}$ In democratic constitution-making, citizens - or their representatives - transcend the role of political partisans and actualize a common will that brings forth a higher law acceptable to all, one that can normatively constrain and thus legitimize the outcomes of the rough and tumble of ordinary politics. While authors who defend this approach are usually keen to emphasize that the character of the process of

\footnotetext{
${ }^{8}$ Some prominent recent literature on constituent power was clearly influenced by Böckenförde's work. See for example Kalyvas, 'Popular Sovereignty, Democracy, and the Constituent Power' (n 1) and Loughlin, 'The Concept of Constituent Power' (n 1).

${ }^{9}$ See Hannah Arendt, On Revolution (Penguin 2006), as well as Bruce Ackerman, We the People, Volume 1: Foundations (Harvard University Press 1993); Jürgen Habermas, Between Facts and Norms: Contributions to a Discourse Theory of Law and Democracy (William Rehg tr, MIT Press 1996); Ingeborg Mauss, Über Volkssouveränität. Elemente einer Demokratietheorie (Suhrkamp Verlag 2011); Andrew Arato, Post Sovereign Constitution-Making: Learning and Legitimacy (Oxford University Press 2016).
} 
constitution-making is what gives rise to the legitimacy of the constitution, ${ }^{10}$ a view of this sort is vulnerable to be bent into a more outcome-oriented understanding of constitutional legitimacy. An inclusive, deliberative, and consensual process of constitution-making is likely to bring forth a constitution that protects individual and minority rights and that contains assurances against overbearing majoritarianism. ${ }^{11}$ This, it might be argued, is what recommends inclusive, deliberative, and consensus-oriented methods of constitution-making. It is the kind of process of constitution-making most likely to lead to outcomes that normative theory independently shows to be essential requirements of constitutional legitimacy. In this liberal picture, developed most clearly in the Rawlsian tradition, exercises of constituent power are, at best, instrumentally valuable, but they are not what ultimately legitimizes a constitution. What makes a constitution legitimate, rather, is its conformity to certain antecedent normative standards, which are to be defined on the philosophical armchair, and which are at best contingently related to actual processes of constitution-making. ${ }^{12}$

This tendency to collapse constituent process into (liberal) substance clearly threatens to empty appeals to constituent power of their legitimatory significance. If a substantive normative assessment of the outcomes of the process of constitution-making is needed to

\footnotetext{
${ }^{10}$ See Arato, Post Sovereign Constitution Making (n 9) 1-15.

${ }^{11}$ See Arato, The Adventures of the Constituent Power (n 2) 365-391.

12 See John Rawls, Political Liberalism. Expanded Edition (Columbia University Press 2005) 231-240. Rawls argues that a democratic constitution 'fixes once and for all' certain constitutional essentials, as explicated in a philosophical theory of political justice. He goes on to claim that it is 'through these fixed procedures that the people can express [...] their reasoned democratic will, and indeed without those procedures they cannot have such a will' (ibid 232). Rawls also denies that a constitutional amendment that would violate one of the constitutional essentials could be valid (see ibid 239). Here, it is the outcome of the process of constitutionmaking that determines whether the constitution can be attributed to an (ideal) will of the people, not the will of the people that legitimates the constitution.
} 
certify the authenticity of constituent power, then the fact that a constitution was produced by constituent power will have no essential bearing on its legitimacy. An imposed constitution, provided that it exhibits the right substantive content, would have to be regarded as equally legitimate. Many contemporary theorists of constituent power abhor this implication of substantive liberal constitutionalism. They turn to Schmitt (and Böckenförde) in order to find tools to block liberal attempts to downplay the significance of actual production by constituent power for constitutional legitimacy.

Schmitt's theory of constituent power is the most clearly articulated conception of what I have elsewhere referred to as 'strong popular sovereignty" 13 or of what Andrew Arato has called 'sovereign constituent power'. ${ }^{14}$ A theory of strong or sovereign constituent power rejects the claim that exercises of constituent power, to be authentic, must conform to procedural principles of inclusiveness and deliberative openness - be they moral or legal. What is more, such a theory denies that authentic exercises of constituent power must result in certain substantive outcomes predetermined by normative reasoning. Any outcome is to be regarded as legitimate, given only that it results from the will of the people. To radicalize our theory of constituent power in these two respects is the only way, or so the current defenders of strong popular sovereignty believe, to provide appeals to constituent power with a distinct and irreducible relevance in accounting for the legitimacy of a democratic constitution. It is the only way to make sure that a democratic constitution is truly the people's constitution.

The systematic thesis defended in this paper is that strong theories of constituent power cannot live up to their promise. On closer inspection, the claim that a strong constituent

13 See Lars Vinx, 'The Incoherence of Strong Popular Sovereignty' (2013) 11 International Journal of Constitutional Law 101; George Duke, 'Strong Popular Sovereignty and Constitutional Legitimacy' (forthcoming) European Journal of Political Theory.

${ }^{14}$ See Arato, The Adventures of the Constituent Power (n 2) 45-105. 
power will serve to account for the legitimacy of a democratic constitution turns out to be irredeemably confused. A strong theory of constituent power must necessarily fail, for purely conceptual reasons, to explicate the supposed link between a constituent will and the constitution it that produces, and to do so in a way that can sustain a constitution's claim to legitimacy. Attempts to play off a radical, Schmittian understanding of popular sovereignty against liberal constitutionalism cannot, therefore, achieve their own declared goal, that is, to show that an appeal to the constituent will of the people is a distinctive ground of the legitimacy of a constitution.

This thesis will be developed here in two major steps. Section 2 of this paper offers an indepth exegesis of Ernst-Wolfgang Böckenförde's adaptation of Schmitt's approach to constituent power. A thorough understanding of the inner workings of strong theories of constituent power is necessary to clearly diagnose their flaws, and this understanding can best be achieved by a careful inspection of the nuts and bolts of what is perhaps the most systematic statement of such a theory. Particular emphasis will be put, in this first step, on explaining precisely why the strong theory of constituent power must reject any antecedent moral, procedural, or legal restraints on the will of the people. This will permit us to see that the strong theory of constituent power, in order to determine the identity of the constituent will, is forced to adopt a Schmittian understanding of political community. Sections 3-5 will go on to offer a sustained critique of the claim that a strong theory of constituent power, tied as it is to a Schmittian conception of the political, can account for the legitimacy of a democratic constitution. As we will see, this claim is open to three different interpretations that focus, respectively, on the values of self-government, democratic political stability, and undiluted identity. The three corresponding attempts to explicate constitutional legitimacy will be addressed and refuted in their turn. We thus arrive at the conclusion, in section 6 , that the attempt to develop a radical theory of constituent power inspired by Schmitt must fail to 
shed light on the legitimacy of a democratic constitution. Whether a less radical conception of democratic constituent power is nevertheless needed to explicate democratic constitutional legitimacy is a question that I will not attempt to answer here.

\section{Böckenförde on the Constituent Power of the People}

2.1 The concept of constituent power, according to Böckenförde, is a 'concept of legitimation' that serves to ground the 'normative validity' of a constitution. ${ }^{15}$ If that is indeed the task of the concept of constituent power, we are entitled to ask whether Böckenförde's theory of constituent power succeeds in providing a convincing account of the legitimacy of constitutional law. Before we can address this question, we must make sure to understand the theory accurately and in enough detail.

Böckenförde talks of the 'normative validity' of constitutional law as well as of its legitimacy. Though Böckenförde rejects natural law theory, his use of the term 'validity' does not seem to embrace the modern positivist distinction between mere legal validity and practical legitimacy. Böckenförde is not terribly explicit about what exactly he understands by 'normative validity', but the term, in his usage, does appear to carry connotations of practical justification. ${ }^{16}$ To say that the normative validity of constitutional law and its legitimacy are one and the same thing is to say, presumably, that normatively valid constitutional law is, in some sense, practically justified and therefore deserving of deference and compliance on the part of its addressees.

\footnotetext{
${ }^{15}$ Böckenförde, 'The Constituent Power of the People' (n 6) 171.

${ }^{16}$ See ibid 170-171, 176.
} 
What makes constitutional law normatively valid or legitimate, according to Böckenförde, is that it is produced by constituent power. A constituent power, whatever else it may be, is a de facto power that creates a constitution, through a process of constitution-making that unfolds in actual historical time. And a constitution enjoys normative validity or legitimacy as a result of the fact that it has been created by (and continues to be endorsed by) constituent power. ${ }^{17}$ For reasons that will become clear, Böckenförde is committed to the view that production by constituent power is not merely a necessary, but also a sufficient condition for the normative validity or legitimacy of a constitution. Any constitution that is the product of a true or authentic constituent will is legitimate, regardless of its material content.

Needless to say, every existing constitution in the functional sense of the term, i.e. every hierarchically uppermost level of positive law, is produced by some de facto power or other. If every power that can produce a constitution in the functional sense was a constituent power, and if production by constituent was sufficient to legitimate a constitution, all existing constitutions would be equally legitimate. The notion of constituent power would obviously be unable, in that case, to play the role of a concept of legitimation that helps us to distinguish between legitimate and illegitimate constitutions. To be legitimate or to have normative validity, a constitution must therefore be the causal product of a certain kind of political will, one that, in contrast to other de facto powers that might be able to impose a constitution, can also legitimate it.

2.2 Why does the legitimacy of a constitution depend on production by constituent power? Böckenförde's answer to this question is that there is no viable alternative to a theory of constitutional legitimacy that appeals to production by constituent power.

\footnotetext{
${ }^{17}$ See ibid 171.
} 
The most obvious alternative approach to the problem of constitutional legitimacy is to embrace some version of the view that the legitimacy of a constitution results from its conformity with certain moral principles - principles the normative validity of which is independent of and prior to positive constitutional law and that can therefore form an external normative yardstick for the assessment of legitimacy of positive constitutional law.

Böckenförde's dismissal of this alternative is framed in terms of a rejection of traditional natural law theory, and more specifically of the view that there are norms of natural law that constrain even the makers of a constitution. ${ }^{18}$ Such a view is to be rejected, Böckenförde thinks, for the reason that norms of natural law lack the effectiveness that is a necessary ingredient of legal validity. In order to be sufficiently stable, a constitutional system must possess sociological legitimacy, it must be regarded as justified or be believed to be legitimate by (a sufficient number of) those whose behavior it purports to govern. There is no system of natural law that, qua system of natural law, meets this standard of effectiveness. The legal validity of any supposed norm of natural law must therefore depend on the fact that the power that produced some positive constitutional system chose to incorporate it, and not on its intrinsic correctness. ${ }^{19}$ Remember that Böckenförde does not distinguish very sharply between legal validity and legitimacy or normative validity. This suggests the further conclusion that it is not merely the validity but also the legitimacy of official reliance on a supposed norm of natural law that depends on the latter's incorporation into the law of the constitution by an act of constituent power. If this is granted, it follows that norms of natural

\footnotetext{
18 The claim that a theory of constituent power must reject natural law is often endorsed by proponents of constituent power, sometimes with reference to Böckenförde. See Kalyvas, 'Popular Sovereignty, Democracy, and the Constituent Power' (n 1) 228 and Loughlin, 'The Concept of Constituent Power' (n 1) 221.

${ }^{19}$ Böckenförde, 'The Constituent Power of the People' (n 6) 171, 184-185.
} 
law cannot legitimate a positive constitutional system, since their own legitimacy derives from the will that creates the positive constitution.

Böckenförde's critique of natural law has important negative implications for the question of what makes a power an authentic constituent power. To determine whether it has constitutional standing, we need to figure out whether a purported norm of natural law has been incorporated into the constitution by the constituent power. And the answer to this question must not depend in any way on moral judgment, but only on clearly ascertainable empirical fact. Suppose we held that a constitution-making power is an authentic constituent power only on the condition that it is committed to implementing certain substantive moral principles that figure as antecedent standards of legitimacy. If we adopted a view of this sort, then the claim that the constitution is legitimate because it was produced by an authentic constituent power would collapse into a form of the natural law that Böckenförde is concerned to reject. We would be claiming, at least indirectly, that the constitution is legitimated by the fact that it expresses certain normative principles to which even the constituent will is bound. Böckenförde unambiguously rejects any such view by expressing his explicit agreement with the notion that the constituent power, like the sovereign of old, is legally free from externally imposed normative constraint. ${ }^{20}$

2.3 This strategy for avoiding a collapse of the notion of constituent power into a natural law theory might seem to put Böckenförde's view in uncomfortable proximity to positivist theorists of legal system like Kelsen or Hart. Theorists in that tradition would presumably agree with Böckenförde's claim that the validity of a law depends on its effectiveness, which

\footnotetext{
${ }^{20}$ See ibid 179-185.
} 
in turn depends on incorporation into positive law. ${ }^{21}$ Kelsen famously claimed that the law can take any content. ${ }^{22}$ This is really just another way of saying that a de facto power that is strong enough to produce a novel constitution, and to ensure sufficient compliance with it, is not bound to any prior normative constraints in devising that constitution's content. The trouble, of course, is that such a view does not provide any conceptual space for treating the reference to a constitution-producing power as legitimating.

In Kelsen's view, jurisprudence, to get the business of legal science going, must assume that the de facto power that created the constitution, whatever power that might have been, was legally authorized to do so. And once that assumption is made, all further normative questions are to be settled in accordance with the legal standards validated by that initial hypothesis. The law regulates its own creation and application, and it does not point to a legitimating origin that stands outside of its internal, self-referential normativity. From inside a legal order - and every jurisprudential judgment must, according to Kelsen, assume the point of view of some legal order or other - acts of constituent power thus become invisible. According to Kelsen, it is therefore meaningless, from a legal point of view, to claim that some legal orders are normatively valid or practically legitimate, in some sense that goes beyond mere system-internal legal validity, because they have been produced by constituent power while others are not because they have not. Talk of sovereignty, rightly understood, indicates nothing more than the normative independence of a legal order. ${ }^{23}$

\footnotetext{
${ }^{21}$ See for example Joseph Raz, ‘Authority, Law, and Morality’ (1985) 68 The Monist 295.

${ }^{22}$ See Hans Kelsen, Introduction to the Problems of Legal Theory. A Translation of the First Edition of the Reine Rechtslehre or Pure Theory of Law (Bonnie-Litschewski Paulson and Stanley Paulson trs and eds, OUP 1992) 23-25.

${ }^{23}$ See Hans Kelsen, Allgemeine Staatslehre (Julius Springer 1925) 102-115; Lindahl, 'Constituent Power and Reflexive Identity' (n 1) 10-14.
} 
In order to escape this trap, Böckenförde must conceive of a (legitimate) constitution as one that is produced by a constituent will that stands altogether outside of the law, that need not have been authorized by law to produce the law in its normative validity. If the reference to constituent power as a legitimating origin is to stay clear of a Kelsenian reduction of legitimacy to mere legality, the authenticity of constituent power cannot depend on whether constituent power is exercised in accordance with legal requirements, whether they be procedural or substantive, that are laid down in or presupposed by existing positive constitutional law. Böckenförde consequently makes it clear that the constituent power cannot exist 'within or on the basis of the constitution'. ${ }^{24}$ Rather, it must 'precede the constitution and the pouvoirs constitués established and limited by it' ${ }^{25}$

2.4 Who, then, is the bearer of (authentic) constituent power? The reference to constituent power is supposed to legitimate the constitution, and to do so in a way that avoids both a collapse into natural law theory as well as a positivist reduction of legitimacy to mere legality. Böckenförde argues that this compels the conclusion that the people are (or rather, that a people is) the only possible bearer of constituent power. ${ }^{26}$

The conception of constituent power outlined so far clearly implies that constituent power cannot be attributed to any person or institution - say, a parliament deciding under a rule of supermajority - the normative power of which derives from an already existing framework of positive constitutional law. Constituent power must be attributable without any reference to positive law. Another relevant implication of the argument so far is that recourse to the law of

\footnotetext{
${ }^{24}$ Böckenförde, 'The Constituent Power of the People' (n 6) 171.

${ }^{25}$ Ibid.

${ }^{26}$ Ibid 172-175.
} 
nature (or, for what it is worth, the law of God) will fail to pinpoint a bearer of constituent power. If norms of natural (or divine) law are valid only in virtue of incorporation by constituent power, they cannot themselves determine the bearer of constituent power.

We are left with the claim that constituent power is vested in the people, as the only possible alternative. Böckenförde remarks that the notion of constituent power was introduced to justify the people in challenging the position of the monarchic sovereign. ${ }^{27}$ It is thus historically at home in the context of the constitutional theory of democratic revolution. The people's claim to constituent power, Böckenförde suggests, accompanies the shift to a social condition in which ideologies that ground the basis of legitimate normative order in God's will or in nature, and thus remove it from human choice, have lost their purchase. The only constituent act, therefore, that is likely to be factually successful today is one that presents itself as taking place in the name of a people and that is recognized by the people in question as taking place in its name. ${ }^{28}$

2.5 What group, exactly, does the talk of 'the people' refer to in this context? One natural way to conceive of the people does not appear to be available to Böckenförde. A tradition that stretches all the way back to Aristotle ${ }^{29}$ identifies the boundaries of political community by reference to the laws of the existing constitution. In this conception, the group that we call 'the people' is comprised of all citizens, and citizens are those who, under the laws of the existing constitution, enjoy rights of political participation. This solution would conflict with

\footnotetext{
${ }^{27}$ Ibid $172-173$.

${ }^{28}$ Ibid 171, 184. All these claims are adapted from Schmitt. Compare Carl Schmitt, Constitutional Theory (Jeffrey Seitzer tr, Duke University Press 2008) 126-130.

${ }^{29}$ See Aristotle, The Politics (T.A. Sinclair tr, revised by T.J. Saunders, Penguin 1981) 167-175.
} 
the pre-legal nature of constituent power stressed by Böckenförde, and he consequently appears to disavow it. ${ }^{30}$ To determine the constituent power with reference to the laws of the constitution that is to be legitimated would be openly circular, and a reference to the laws of any other constitution than the one that is to be legitimated - say, to the laws of the constitution that is to be replaced - could not be binding. Neither option would permit us to escape the Kelsenian legality-trap that disappears constituent power. Böckenförde, then, must build a conception of the people as constituent power that does not rely on appeal to existing constitutional laws of citizenship.

However, the claim that the people is capable of acting as a constituent power before having been organized by legal rules of some sort, is open to an obvious challenge. To be sure, those who make a novel constitution typically claim to act and decide in the name of and in line with the will of the people. But such attributions, it might be argued, are obviously fictional. What typically happens is that a preponderant political power forces itself on society, from outside the realm of legality. And fictional attributions to the constituent power of the people can have no legitimating import. ${ }^{31}$ All that can be said in the light of these facts, with Kelsen (or, for that matter, Hobbes or Kant), is that if revolutionaries are successful in establishing a novel constitution, jurisprudence must assume that the constitution they have created is legally valid, though not necessarily legitimate.

Böckenförde cannot circumvent this problem by claiming that the constituent power ought to be delimited in terms of a moral ideal of political inclusion. One can demand, of course, that the people should include all those who will be subject to the law of the constitution, or even all those who are affected by it. And one might then say that a constitution is legitimate if and

\footnotetext{
${ }^{30}$ Böckenförde, 'The Constituent Power of the People' (n 6) 173, 175.

${ }^{31}$ David Dyzenhaus, 'The Politics of the Question of Constituent Power' in Loughlin and Walker (eds), The Paradox of Constitutionalism (n 1).
} 
only if it is such that it could not be reasonably rejected, from behind a veil of ignorance, by any of those who will be subject to $\mathrm{it}^{32}$ or that it is legitimate if and only if all those who will be subject to it would have come to reach a consensus on it, in a fully inclusive and deliberative discursive process. ${ }^{33}$ These approaches are normativist regressions into what Böckenförde must regard as a form of natural law and thus do not solve the problem of fictional attribution.

To address the problem of fictional attribution, Böckenförde takes inspiration from Carl Schmitt's conception of political community. ${ }^{34}$ Schmittian political communities, supposedly, have a real existence as well as a real capacity to act, apart from and prior to legal organization. They can therefore play the role of non-fictional points of attribution of constituent power. ${ }^{35}$ What is more, while Schmittian political communities are constituted by shared normative commitments, their identity is not defined by natural moral standards that are held to be binding on constituent will. ${ }^{36}$

\footnotetext{
${ }^{32}$ See Rawls, Political Liberalism. Expanded Edition (n 12).

${ }^{33}$ See Habermas, Between Facts and Norms (n 9).

${ }^{34}$ See Carl Schmitt, The Concept of the Political. Expanded Edtion (George Schwab tr, University of Chicago Press 2007).

35 See Schmitt, Constitutional Theory (n 28) 75-77, 125-126 and Schmitt, The Concept of the Political (n 34) 25-37. For the connection between Schmitt's understanding of political community and his constitutional theory see Ellen Kennedy, Constitutional Failure. Carl Schmitt in Weimar (Duke University Press 2004) 92-118; Hasso Hofmann, Legitimität gegen Legalität. Der Weg der politischen Philosophie Carl Schmitt's (Duncker \& Humblot 2002) 78-167; Reinhard Mehring, Pathetisches Denken. Carl Schmitt's Denkweg am Leitfaden Hegels: Katholische Grundstellung und antimarxistische Hegelstrategie (Duncker \& Humblot 1989) 76-105; Lars Vinx, 'Carl Schmitt's Defense of Sovereignty' in David Dyzenhaus and Thomas Poole (eds), Law, Liberty, and State: Oakeshott, Hayek, and Schmitt on the Rule of Law (Cambridge University Press 2015).

${ }^{36}$ See Schmitt, Constitutional Theory (n 28) 126-130.
} 
2.6 To have joint membership in a political community, even without reference to any constitutional or moral framework, a group of people must identify with each other in a certain way, and do so on the basis of a shared marker of identity that is specifiable without reference to law or morality. Individuals who form a people are 'politically uniting and demarcating themselves' from other groups, they form a group which is 'conscious of itself as a political entity. ${ }^{37}$ What it means to unite politically, for Böckenförde, is to be explicated with reference to Schmitt's understanding of the political. ${ }^{38}$ A group of people form a political community or a constituent power if they recognize one another as members of the same group, on the basis of some concrete marker of identity, and if that identification engenders a willingness, on the part of the members, to draw a collective distinction between friend and enemy. ${ }^{39}$

Whether some group meets these two conditions, and thus qualifies as a political community, is a factual question. Either a group of people identify concretely, and in a way that will support the drawing of a friend-enemy distinction, if there is a perceived need to do so, or they do not. But if they do - and this is Schmitt's answer to the claim that attributions to the

\footnotetext{
${ }^{37}$ Böckenförde, ‘The Constituent Power of the People' (n 6) 173.

${ }^{38}$ See Ernst-Wolfgang Böckenförde, 'The Concept of the Political: A Key to Understanding Carl Schmitt's Constitutional Theory' in David Dyzenhaus (ed), Law as Politics: Carl Schmitt's Critique of Liberalism (Duke University Press 1998).

${ }^{39}$ Künkler and Stein rightly point out that 'neither Böckenförde nor the Federal Constitutional Court employs a primordial notion of the people' (see Künkler and Stein, 'State, Law, and Constitution', n 7, 23), i.e. one that treats political identity to be fixed by biological descent. I am not convinced, though, that this marks a profound difference from Schmitt. At least in work published before the Machtergreifung, Schmitt never takes the view that a marker of political identity must be racial or be based on biological descent and his theory of the political, as far as I can see, does not require such an interpretation (compare $\mathrm{n} 56$ below).
} 
people are irredeemably fictional - then we can attribute actual existence to a political community, existence as a power that is capable of real action, capable of exercising real causal influence on history, politics, and law.

If constituent power is a power that is exercised - and that can only be exercised - by a people in the Schmittian sense, it must follow that there can be no exercises of constituent power where there is no political community in the Schmittian sense. And if a constitution is legitimate if and only if it has been produced by, and continues to be supported by, a constituent power it will also follow that there can be no legitimate constitution in the absence of a Schmittian political community that produces and continues to endorse it.

2.7 Böckenförde has a tendency to identify Schmittian political identity with 'ideas of order' or with 'ethical-moral views and principles' that are said to be 'alive and present within the people or the nation. ${ }^{40}$ He claims, with reference to Hermann Heller, that a small part of the content of such any such idea of order will be made up by normative principles with universal applicability. ${ }^{41}$ Though Böckenförde adamantly denies that the constituent will could be bound by antecedent legal constraints, he therefore claims, with reference to the fact that a constituent decision must be a decision for the production of a legal framework that is animated by some idea of order, that it would be wrong to regard the constituent will as altogether arbitrary. ${ }^{42}$

This raises the question whether a political identity that is fit to serve as an idea of constitutional order is, after all, bound to objective normative standards of some sort. It might

\footnotetext{
${ }^{40}$ Böckenförde, 'The Constituent Power of the People' (n 6) 184.

${ }^{41}$ Ibid 183. Compare Hermann Heller, Staatslehre (J.C.B. Mohr/Paul Siebeck 1983) 221-222.

${ }^{42}$ See also Loughlin, 'The Concept of Constituent Power' (n 1) 230-231.
} 
be argued, for instance, that there are certain values intrinsic to the very notion of legality, and the implication might then be that a constituent will that aims to create a genuinely legal order must be committed to the implementation of those values. This, in turn, would explain why a constituent will can be said not to be arbitrary. There would be normative conditions, in other words, on the very constitution of such a will - as opposed to limitations imposed by superior legal authorities or by moral norms external to legality - that impose restrictions on what such a will can do. ${ }^{43}$

Though Böckenförde toys with this idea, I do not think that his overall conception of constituent power could be compatible with any very interesting conception of intrinsic limitation - a point which Böckenförde himself seems to acknowledge. ${ }^{44}$ The reason for this is simple: If it was true that an authentic constituent will must be committed to the implementation of certain values intrinsic to legality, then the conformity of the constitutional order produced by constituent power with those values would become at least a necessary condition of constitutional legitimacy. But that claim is just the theory of natural law - which Böckenförde has already rejected - in a different, Fullerian guise. It conflicts with the key thesis that Böckenförde is concerned to defend, namely that it is not merely a necessary but

\footnotetext{
${ }^{43}$ This idea has been explored, though in rather different ways, in the work of Loughlin and Dyzenhaus. See Loughlin, Foundations of Public Law (n 1); Dyzenhaus, 'The Politics of the Question of Constituent Power' (n 25); David Dyzenhaus, 'Constitutionalism in an Old Key: Legality and Constituent Power' (2012) 1 Global Constitutionalism 229.

${ }^{44}$ See Böckenförde, 'The Constituent Power of the People' (n 6) 180, where Böckenförde emphasizes that an internal limitation 'remains a self-constraint; since the pouvoir constituant does not stand under the constitution but establishes and legitimizes the latter in the first place, this limitation cannot be regarded as an imposed legal constraint.'
} 
also a sufficient condition of constitutional legitimacy for a constitution to have been produced by a constituent power that is not bound to antecedent standards of natural law. ${ }^{45}$

Böckenförde's considered view, therefore, must be that the constitution can take any content, without losing its normative validity, as long as it is produced by an authentic constituent power. The traditional claim of sovereignty is reformulated as the claim, then, that while the people must be committed to some idea of order or other to create a constitution, there are no antecedent restrictions on what idea of order they need to be committed to. An idea of order that is expressed in some constitutional framework has legitimacy not because it conforms to some a priori normative standard, but rather because it has been chosen by the people. It follows, of course, that there is no ground, from within Böckenförde's conception of constituent power, to argue that it is a criterion of the authenticity or normative validity of an exercise of constituent power that it produce a constitution with a specific material content.

2.8 It might well be asked how this view differs from the claim that any de facto power that is capable to produce a constitution is an authentic constituent power and that all constitutions

\footnotetext{
${ }^{45}$ Böckenförde at one point concedes that a constitution that has been produced by constituent power might be legally valid, but still lack legitimacy or normatively validity, in case it violates human rights or fundamental principles of natural law (see ibid 183). This claim, though, clearly stands in tension with Böckenförde's overall approach to constituent power, which is concerned to defend the claim that constituent power produces a constitution in its normative validity. One cannot have it both ways here: Once it is admitted that constituent power does not necessarily legitimate its product, the theory of constituent power will tend to become pointless. We surely do not need a theory of constituent power to explain mere legal validity, as Kelsen and Hart have shown. And if the legitimacy of a constitution's content turns on conformity to antecedent standards of natural right the reference to constituent power will be of limited relevance, at best, to assessing a constitution's legitimacy.
} 
are therefore equally legitimate. The answer, of course, is that the specific mode of production (and continuing endorsement) matters in this context. A mode of constitutional production that could be regarded as an exercise of constituent power - in Böckenförde's sense of the term - will exhibit two features that distinguish it from other, non-legitimating modes of constitutional production. Both of these features can be drawn from the notion of political community Böckenförde adapts from Schmitt.

First, a constitution produced by constituent power - or put differently: a constitution that a Schmittian political community gives to itself - is not imposed upon members of the political community whose constitution it is by some power external to the group. Rather, the constitution is the product of the collective action of the members of the group and thus expresses their own understanding of their political identity or, what amounts to the same thing, their preferred idea of public order. ${ }^{46}$ Second, the de facto power of the group to produce a constitution results from a political identification, on the part of individual members, that is voluntary. ${ }^{47}$ Schmitt conceives of membership in a political community, and of participation in its collective action, as the result of an uncoerced allegiance to the politydefining identity or idea of order that is to be expressed in the constitution. The power of the

\footnotetext{
${ }^{46}$ See Schmitt, The Concept of the Political (n 34) 45-53.

${ }^{47}$ I do not mean to imply here that the identity that constitutes political community must be one to which everyone could freely choose to subscribe. The claim is merely that those who do identify politically do not do so as a result of coercion. This does not rule out that the marker(s) of identity by which members of a group identify politically might focus on ascriptive characteristics or on characteristics the acquisition of which would require lengthy acculturation. In such cases, the political identity in question would likely exclude some potential members of political community against their will.
} 
popular sovereign is thus grounded in a kind of normative consensus among members of political community. ${ }^{48}$

I concede that these two characteristics allow Böckenförde to distinguish a de facto power that, supposedly, produces a constitution in its normative validity from a mere de facto power that, while it may be able to impose a constitution by force or trickery, could not confer legitimacy on its product. It would thus be wrong to hold that Böckenförde's notion of constituent power is compelled to recognize any de facto power capable of producing a constitution as an authentic constituent power.

This is not to deny that it may be complicated to figure out whether some actual act of constitution-making met the two characteristics for constituent authenticity outlined here. Böckenförde, echoing Schmitt, emphasizes that acts of constitution-making that would have to be regarded as authentic exercises of constituent power could take place in very different and procedurally diverse ways. ${ }^{49}$ This is an inevitable consequence of the strong conception of constituent power as a completely meta-legal power unrestricted by existing positive constitutional norms and by standards of natural law. All that can be said from the point of view of theory is that an act of constitution-making that purports to be an exercise of constituent power must, in some way or other, engage the people, those who are regarded as members of political community, and its success must causally depend on the voluntary acceptance and support of the constitution-making act by the members of that group. Any evaluation of particular cases will have to be context-sensitive. For purposes of argument, I

\footnotetext{
${ }^{48}$ See for a contemporary version of this point Kalyvas, 'Popular Sovereignty, Democracy, and the Constituent Power' (n 1) 236.

${ }^{49}$ Böckenförde, 'The Constituent Power of the People' (n 6) 176-179. Compare Schmitt, Constitutional Theory (n 28) 130-135.
} 
will concede that it is possible to evaluate individual cases in light of the theory and to assess claims to constituent authenticity.

2.9 With this outline of Böckenförde's conception of constituent power in hand, it is now time to address the key question. Böckenförde introduces the concept of constituent power as a concept of legitimation. A constitution is said to be legitimate if and only if it has been produced by constituent power. What are the reasons for holding that a constitution that has been produced by constituent power - understood in Böckenförde's terms - is therefore to be regarded as normatively valid or legitimate? In what follows I will try to work out three different answers to this question that are intimated in Böckenförde's discussion, and I will make an attempt to assess whether these answers are convincing.

\section{Böckenförde and the Argument from Democratic Self-Government}

3.1 It might seem that the answer to the question of why a constitution is legitimate if and only if has been produced by constituent power is blindingly obvious. A constitution produced by the people is a constitution that those who are expected to comply with it have given to themselves. A constitution that has been produced by constituent power thus conforms to the basic democratic requirement that the people govern themselves, while a constitution imposed on the people in some other way does not. Let us call this approach the argument from democratic self-government.

3.2 Some proponents of this argument hold that the constituent power must include all those who are to be subject to (or who will be affected by) the constitution that is to be produced. 
This demand for inclusion ultimately stems from the principle that the political authority that is to be exercised under the constitution must be justifiable to all who are expected to recognize that authority. ${ }^{50}$ Moderate theorists of constituent power who put emphasis on the argument from democratic self-government typically take the view that this demand for justification can only be met in an actual process of constitution-making, that is, that it cannot be discharged merely by engaging in Rawlsian thought experiments about what ideally rational agents couldn't reasonably reject. ${ }^{51}$ Actual production by constituent power, given that the process of constitution-making is sufficiently deliberative and consensus-oriented, is held to engender constitutional legitimacy because it is assumed that decisions on the content of the constitution will be guided by a shared understanding of the common good. At any rate, affected groups that are dissatisfied with a proposed constitution are to have the power to speak up and to demand revisions. The constitution, once duly approved, thus expresses a consensus on the part of all major social groups who are asked to respect it, or at least a compromise that all such groups have decided they can live with. ${ }^{52}$

It should be clear that Böckenförde's conception of constituent power is profoundly at odds with this conception of constitutional legitimacy by constituent production. The reason for this is that Böckenförde's conception of constituent power does not allow us to determine who belongs to the people - and is consequently entitled to demand standing in the process of constitution-making - in advance of actual processes of constitution-making, by resort to a normative standard of inclusion, such as the principle that all those who are going to be

\footnotetext{
${ }^{50}$ See Rainer Forst, The Right to Justification: Elements of a Constructivist Theory of Justice (Columbia University Press 2011).

${ }^{51}$ See Jürgen Habermas, 'Reconciliation Through the Public Use of Reason' (1995) 92 Journal of Philosophy 109.

${ }^{52}$ See Arato, Post Sovereign Constitution Making (n 9).
} 
subject to an authority have standing to demand that it be justified to them. On Böckenförde's conception of constituent power, the substantive outcome of the constituent process must be determinative of who truly belongs to the people that produces the constitution.

Let me try to explain. As we have seen, joint membership in political community, for Böckenförde as well as for Schmitt, depends on sharing and on being committed to a concrete marker (or set of markers of) political identity. This identity is to be expressed in the constitution, more precisely in the constitution's underlying idea of order, in what Schmitt called the "positive constitution. ${ }^{, 53}$ But the political community or constituent power that is itself formed by that identity is said exist prior to the constitutional laws which it gives itself. If the constituent power was itself constituted by constitutional laws, exercises of constituent power could not legitimate their product. It would appear to follow that existing rights of citizenship cannot ground an indefeasible claim to inclusion in constituent community. A political community must have the power to identify its own boundaries without reference to existing law, if its choices are to offer a non-circular legitimation of the legal-constitutional product, and this entails that it is always possible that a constituent community will conceive of its own identity in a way that excludes some of those who hold rights of citizenship. ${ }^{54}$ Such

\footnotetext{
${ }^{53}$ See Schmitt, Constitutional Theory (n 28) 75-88.

${ }^{54}$ It is hard to make out whether Böckenförde endorses this consequence of his approach to constituent power. There are several passages in Böckenförde's work that suggest that he would be staunchly opposed to the exclusion of legal citizens from participation in the exercise constituent power, or more generally from being recognized as members of the political nation. Böckenförde condemns the persecution of German Jews in the Nazi period as a civic betrayal of loyal and well-assimilated fellow citizens (Ernst-Wolfgang Böckenförde, 'The Persecution of the German Jews as a Civic Betrayal' in Böckenförde, Constitutional and Political Theory, n 6) and he expresses agreement with the view that guest workers who have developed sufficient roots in German society ought to be given a path to citizenship (Ernst-Wolfgang Böckenförde, 'Citizenship and the Concept of Nationality' in Böckenförde, Constitutional and Political Theory, n 6). Nevertheless, some of Böckenförde's
} 
exclusion from constituent community does not have to take the form of open expulsion from society or of a denial of formal participation in the constituent process (i.e. of the individual right to vote in a constitutional referendum or to elect members of a constituent assembly). It might simply take the form of a refusal, on the part of a numerical majority, to recognize a minority's demand that its identity be accommodated by the constitution which is to be produced, and to give that minority the procedural standing to enforce that demand.

What is more, a people's choice of political identity cannot, for reasons already discussed above, be constrained by supposed normative standards of natural law or pre-legal morality, like a requirement of universal justification. Such standards have no validity that is independent of incorporation into the constitution by constituent choice. They cannot, therefore, bind a constituent will. As a result, Böckenförde's conception provides no basis for claims to standing in the constituent process that appeal to supposed rules of contextindependent morality or natural law.

Even if we conceive of political identity by reference to a 'natural' criterion like ethnicity, it will likely be impossible to pin down its precise contours independently of a successful act of constitution-making. After all, as Böckenförde rightly emphasizes, a certain communal

discussions of the relation between legal citizenship and membership in the political nation are more ambivalent. One finds passages that imply that legal citizenship does not entail membership of the political nation (Böckenförde, 'The Constituent Power of the People', n 6, 173) or that it does so only on the condition that the legal bond of citizenship is itself reflective of an underlying 'substantial equality' (Ernst-Wolfgang Böckenförde, 'Demokratie als Verfassungsprinzip' in Josef Isensee and Paul Kirchof [eds], Handbuch des Staatsrechts der Bundesrepublik Deutschland, vol I, C.F. Müller, 1987, 918). At one time, Böckenförde rather brusquely rejected the idea that resident non-citizens should be granted rights of political participation in local contexts and claimed that they did not belong to the German people as a 'community of fate' (ibid 904-905). Such claims suggest that the legal right of citizenship, for Böckenförde, is not the real basis of political community, but a right that ought to be a consequence of pre-legal existential belonging. 
identity becomes constitutive of political community - as a real historical force capable of real action - only on the condition that people identify with it intensely enough to be motivated to engage in political action on a historical scale, to participate in acts of constitution-making that implement that identity, if need be against the resistance of the powers that be. ${ }^{55}$ Hence, we cannot precisely determine in advance of actual exercises of constituent power what the political identity of a people is, since one cannot precisely determine in advance of actual processes of constitution-making which understandings of constitutional identity will motivate a people to cross the threshold of the political.

It follows that we cannot first define who is to be included in the constituent power - whether on the basis of the all-affected principle, by appeal to the legal notion of citizenship, or by appeal to some seemingly natural criterion like ethnicity - and then go on to say that the constitution agreed upon by members of that group, in some procedure that is sufficiently consensual to ground the heightened legitimacy of constitutional laws, is the one that is legitimate. Böckenförde's conception of constituent power implies, rather, that only those who identify with the idea of order which has come to be implemented by a successful actual exercise of constituent power truly belong to the people. We need to await the appearance of constituent power to see which idea that is, should there be any doubts, and thus to figure out who truly belongs. ${ }^{56}$ A constituent choice is supposed to express a kind of unanimity - but in

55 Böckenförde, 'The Constituent Power of the People' (n 6) 173. Compare Schmitt, The Concept of the Political (n 34) 37.

56 This bootstrapping in Schmitt's conception of the people is not always recognized. Lindahl, for instance, attributes to Schmitt a substantialist conception of political community that treats the people as 'a secularization of the ens increatum' (Lindahl, 'Constituent Power and Reflexive Identity', $\mathrm{n} 1,17$ ) and then confronts that conception with a non-substantialist or 'reflexive' (and supposedly more palatable) account of political community. But there can be no doubt that Schmitt was well-aware that acts of constituent power can turn out be authentic only from a retrospective perspective, namely that of factual success. See for example Carl Schmitt, 
a Schmittian theoretical context, this condition is satisfied by a virtual (or possibly even by a real) exclusion of dissenters from the constituent process, not by a consensual constitutional accommodation of differing understandings of political identity. If there are those who do not identify with the idea of order that undergirds the legal constitution that has come to be successfully enacted, this only goes to show that they do not truly belong to the people as constituent community. The constitution that has been produced isn't theirs, and it isn't meant to be theirs. It is the constitution made by those and for those who fit into and who identify with the concrete identity or the idea of order which it enshrines, and who have been successful in making that identity prevail.

So suppose that a society is divided into different groups that have different views as to what political identity ought to be expressed by the constitution, and that you are a member of a group whose conception of constitutional identity has lost out in the process of constitutionmaking. The drafters of the constitution refused to accommodate your identity, and the draft was subsequently approved by simple majority in a constitutional referendum or perhaps even only by the majority of votes in a constituent assembly. You will likely argue that the

Volksentscheid und Volksbegehren. Ein Beitrag zur Auslegung der Weimarer Verfassung und zur Lehre von der unmittelbaren Demokriate (Duncker\&Humblot 2014) 76, where Schmitt argues that even a small, but politically active minority might justifiably claim, in a revolutionary space outside the law, to personify the people [my translation]: 'It is precisely the fact that it is not legally organized that then gives it superiority and the political opportunity to refer to itself directly as "the people" and to identify itself with the will of the people. All historical experience shows that it will likely succeed to draw public opinion and the passive majority of voters to its side. If a vote is then organized after the fact, that is a mere formality. Who can claim to be the people, in this sense, is something that no constitution could ever determine. Any multitude that claims to be the people, without being contradicted, can come to be the people. Therewith, that group itself also decides who is acting as the people in concrete political and social reality.' At least for the Weimar-era Schmitt, political identity is as 'reflexive' as it is for Lindahl. 
constitution is illegitimate because it is not expressive of the identity of (all) the people and that there ought to have been some constitutional compromise that takes account of the voices of minorities, such as yours. You will receive the reply, presumably, that those who are unwilling to identify with the political identity enshrined in the constitution, or who simply do not fit in with it, do not truly belong to the constituent people. It follows that you do not have the standing to demand that your views or interests or political identity be accommodated by the constituent choice.

Admittedly, the giving of this retort is subject to constraints of effectiveness. The creation of a constitution requires de facto power, and that power must stem from sufficient popular approval to qualify as constituent power. There must be a sufficient number of members of society who voluntarily identify with the proposed constitution - who see it as theirs, and as legitimate for that reason - for the constitution to come into force as a result of an exercise of constituent power. But this requirement could clearly be satisfied while substantial parts of society are adamantly opposed to the constitutional identity that results from a non-inclusive constituent process.

3.3 What, then, are we to make of the claim that the argument from democratic selfgovernment explains why production by constituent power legitimates a constitution? One might of course take a very short line and demand that an authentic constituent power must be grounded in some norm of democratic inclusion that is not at the disposal of the constituent will. However, one does not even have to take such an openly normative stance to see that Böckenförde's version of the argument from democratic self-government fails to ground the legitimacy of a constitution. 
Appeals to legitimacy are a form of practical justification. If I say that a constitution is legitimate because it was produced by the people, I am addressing myself to someone who questions (or who might potentially question) the claim that the constitution is binding or normatively valid, someone who would like to be offered a reason of some sort for holding it to be obligatory on him. Such a request, it appears, would be unmotivated if it came from someone who already identifies with the constitutional identity that has come to be expressed by constituent choice. For that person, the question of justification of the constitution would not arise, since the constitution already expresses that person's own convictions as to what idea of order ought to be constitutionally enshrined. They do not have to be told that the constitution is legitimate because it was produced by the people, as though the fact that the constitution embeds their own notion of good social order was not enough to make them accept it as justified.

Now assume the point of view of the person who is likely to ask for a justification of the content of the constitution. That must be someone whose notion of good social order is not (or not fully) implemented in the constitution; this discordance is the reason, after all, why that person might be interested to ask for a justification of the constitution's claim to normative validity. To answer such queries by pointing out that the constitution is legitimate because it was produced by the people would be meaningless, for the reason that the complainant is not considered to be (and, given their exclusion from effective voice in the constituent process, has no reason to consider herself) a member of the constituent people. The Schmittian assumption that a true constituent choice, one that does not get caught up in 'dilatory' compromises, must express a unity in substantive political identity simply leaves no room for any practical justification by appeal to constituent power that might endow the constitution with content-independent practical authority, with what Böckenförde calls 'normative validity'. 
We thus arrive at the conclusion that the argument from democratic self-government, at least in any version that might be compatible with Böckenförde's conception of constituent power, cannot explain why production by constituent power ought to legitimate a constitution. On that conception of constituent power, those who might have reason to ask for a justification of the constitution's claim to legitimacy can never be among those to whom the argument from democratic self-government could meaningfully address itself, because they do not truly belong to the people, while those who truly belong will never have reason to ask for such justification.

At the end, Böckenförde's theory implies that complaints against the illegitimacy of a constitutional identity that is imposed on dissenters against their will come down to a question of power: Those who feel excluded from a constitutional identity imposed by majority have the choice to either rebel or to acquiesce. I do not mean to suggest that Böckenförde would welcome this kind of outcome of a constituent process. My point is that there is nothing in the logic of his conception of constituent power that would allow us to say that a constitution that is imposed on dissenting groups, by a majority or those who successfully claim to represent it, is therefore suspect in its legitimacy. A theory that leads to this conclusion must surely be a problematic account of the legitimacy of democratic constitutionality.

\section{Böckenförde and the Argument from Stability/Homogeneity}

4.1 We cannot rest our case with the conclusion that Böckenförde's conception of constituent power fails to justify a constitution to someone who does not fully identify with the idea of order which it enshrines. Perhaps to offer such justification is not what Böckenförde is after when he argues that the reference to constituent power is necessary and sufficient to explain 
the legitimacy of a constitution. His real aim, it appears at times, is to reflect on the conditions of the stability of a constitution and thus of legal order as such. The famous 'Böckenförde-dictum', which claims that a liberal democracy cannot guarantee the social conditions of its own existence, suggests that a concern for democratic political stability is at the heart of Böckenförde's constitutional theory. ${ }^{57} \mathrm{I}$ will refer to this reflection as the argument from stability/homogeneity.

Recall that the argument from democratic self-government held that the constitution is legitimate because it is a framework that the people have given to themselves, an instantiation of democratic self-governance. We have seen that (and why) Böckenförde rejects an inclusive reading of this idea, one that could explain why all affected must recognize the authority of the constitution. But the claim that the constitution is legitimate or normatively valid if and only if the people see it as theirs - if they see it as expressing their own communal identity - can be given a different reading focused on a concern for political stability. It might be argued that a constitution can be stable, in the absence of a universally accepted theory of morality or natural law, only if the people - or the majority of the people see it as theirs, because they consider it to be an expression of their own concrete preconstitutional political identity, as the form that they have given to their public-political life.

This form of identification with a constitution, and the political stability which it allegedly engenders, is possible, Böckenförde argues, only in societies that are 'relatively homogeneous. ${ }^{58}$ In order to form a stable and enduring political association, members of a society must be sufficiently alike, and recognize each other to be so, at least with respect to

57 See Ernst-Wolfgang Böckenförde, 'Die Entstehung des Staates als Vorgang der Säkularisation' in Säkularisation und Utopie. Ebracher Studien, Ernst Forsthoff zum 65. Geburtstag (Kohlhammer 1967) 93-94.

${ }^{58}$ For the emphasis on 'relative homogeneity' see Böckenförde, 'Demokratie als Verfassungsprinzip' (n 54) 929-931; Böckenförde, 'The Concept of the Political' (n 38). 
those concrete markers of identity that happen to have political salience. Such unity - and the attendant conscious delimitation against an excluded other - is necessary, in Böckenförde's view, to allow a people to assume a strong, motivationally efficacious form of ownership of a constitution, to regard the constitution as specifically theirs, as mirroring who they take themselves to be. Böckenförde fears that a non-exclusive political identity, one that is based on the indistinct equality of human beings implicit in the all-affected principle or on the mere accident of legal citizenship, would lack sufficient motivational force to carry a stable constitutional framework. What, in the context of the argument from democratic selfgovernment, seemed to be a disadvantage of Böckenförde's conception of constituent power, its exclusionary implications, now turns out to be a virtue. The exclusionary structure of the conception will tend to justify an interpretation of the constitution that aims to preserve and to defend the social homogeneity that, supposedly, is necessary to achieve political stability.

It might of course be objected that this line of thought tells us nothing about legitimacy, even if its claims are accurate as regards stability. However, a defender of the argument from stability/homogeneity can reply that the conditions of constitutional stability are also the conditions of the existence of a Rechtszustand, of a rightful condition, as opposed to a latent or an open state of nature. A legal system that adequately protects individual freedom and constituted democracy must be backed up by a sovereign authority, one that is a real force, not a mere fictional point of jurisprudential attribution. Hence, those who agree that the existence of a Rechtszustand is categorically preferable to a state of nature have reason to support a Böckenfördian conception of constituent power, and to welcome its stabilityinducing effects, even if they are slightly uncomfortable with its identitarian bent.

I do not wish to contest the stability/homogeneity argument by pointing out once more that the argument does not justify the constitution's claim to practical authority to those who do not fully identify with the identity which it enshrines. That may be true, but it is beside the 
point, once we take the perspective insinuated by the stability/homogeneity-argument. There can be no stability and no legality without (at least potential) political exclusion of an other that is perceived as existentially alien. That may be unfortunate, but it is, or so the argument claims, a fact of political and constitutional life, something that only a hopelessly naïve person would want to deny. And if we want stable democratic legality, then our concern must be with preserving the conditions of constitutional stability, and not with the potentially stability-undermining accommodation of those who might find themselves subjected to an identity-defining constituent choice that excludes them.

4.2 The argument from stability/homogeneity may sound commonsensical. But it is important to be clear about the fact that it is committed to a very strong empirical claim, and one that proponents of the argument do not typically care to defend through systematic and rigorous empirical comparative research. The claim is that there can be no stable democratic constitutional legality without homogeneity-based constitutional ownership, or at least that the existence of stable constitutional legality without such ownership is exceedingly unlikely. If that empirical claim lacks sufficient warrant, then so does the argument from stability/homogeneity, since its justificatory punch depends on the supposed causal link between homogeneity and stable democratic legality. I am not competent myself to offer a systematic and rigorous empirical investigation into this claim. But I would like to register my suspicion that the confidence in its truth that one finds in Böckenförde might be misplaced.

The conjectural explanation for why constitutional stability requires homogeneity that is intimated in some of Böckenförde's relevant work seems to assume that it is possible to treat social homogeneity as a measurable quantity of some sort, that homogeneity is something 
that comes in degrees, like temperature. The more differences there are between social groups, the less homogeneity there is, and the greater the dangers to social or constitutional stability. If there is too much difference, if the degree of heterogeneity passes a certain threshold, the conjecture continues, some social differences will - in a switch from quantity to quality - turn into cleavages that demarcate social groups from one another as mutual enemies that are willing to fight each other for control of society and the state. And once that comes to pass, the constitutional framework of a society will break down and society will descend into an implicit or explicit condition of civil war.

To prevent such intra-societal friend-enemy distinctions from arising, political conflict must, as far as possible, be relegated to the outer bounds of society. It must, ideally, become a phenomenon that occurs only in relations between states, but not within states, as Schmitt argued in his Concept of the Political. And this will be possible only if the personal boundaries of the state as a community of citizens (and legal residents) overlap with the personal boundaries of the underlying political community, either fully or at least to an extent sufficient to give that political community uncontested control over the state. We thus arrive at the conclusion that a system of constitutional legality must be backed up by a metaconstitutional constituent power, and one that wields uncontested control of the state, so as to be sufficiently stable to afford the enjoyment of a democratic Rechtszustand. For this condition of stability to obtain, we need a society that is relatively homogeneous, one whose degree of plurality remains below the threshold at which social differences acquire political salience. 
4.3 There are several problems with this series of conjectures. ${ }^{59}$ A first problem is that there is no non-arbitrary way to measure a society's degree of homogeneity/heterogeneity, to figure out whether a society is in danger of losing the relative homogeneity that will be sufficient for a stable constitutional framework. Members of a society differ in infinitely many ways, almost all of which are, at any given time, politically irrelevant, but most of which could, in some sense of 'could', become politically salient, as Schmitt, for one, would surely have acknowledged. We could try to pick out a number of dimensions of difference that we think are particularly likely to have political significance - distinctions of wealth, race, ethnicity, religion, language, etc. But even if such a list could be drawn up, it seems unlikely that there is any simple correlation between a degree of plurality, so understood, and democratic stability. ${ }^{60}$ Some stably democratic polities, such as the USA, Canada, South Africa, or India, are characterized by several cross-cutting axes of diversity (economic, ethnic, linguistic, and religious), while there are other cases, think of Northern Ireland, where a society is torn apart by one particular cleavage that has acquired political force, even though that same society is highly homogeneous in most other salient respects.

Constitutional stability requires, of course, that a society not be afflicted by an internal cleavage that is political in Schmitt's sense (or at least that one of the two groups, in case

\footnotetext{
${ }^{59}$ See also Gertrude Lübbe-Wolff, ‘Homogenes Volk - Über Homogenitätspostulate und Integration’ (2007) 27 Zeitschrift fur Ausländerrecht und Ausländerpolitik 121.

${ }^{60}$ The empirical literature on this question in comparative political science does not offer much support to the argument from stability/homogeneity. M. Steven Fish and Robin S. Brooks, 'Does Diversity Hurt Democracy?' (2004) 15 Journal of Democracy 154 vigorously deny that a lack of social homogeneity is associated with political instability or democratic failure. Wolfgang Merkel and Brigitte Weiffen, 'Does Heterogeneity Hinder Democracy?' (2012) 11 Comparative Sociology 387 argue that ethnic heterogeneity and identity-based cleavages can impede democratic consolidation. This result falls well short of substantiating the claim that there can be no stable democracy without homogeneity.
} 
there is such a cleavage, is sufficiently marginal not to constitute a real threat to constitutional stability). But the truth of this claim does not entail that there is any interesting empirical relationship between a society's relative degree of social homogeneity and its political stability. Of course, a society, if it is to enjoy peace, must not be divided in any one respect that separates its members into factions that are prepared to go to war to impose their political goals on their opponents. But this is a bit like saying that there will be peace only if people do not fight. The answer to the empirical question whether such confrontation is less likely to occur in a society that is homogeneous in more respects than some other society cannot be inferred from Schmitt's definition of political community.

More importantly, the tautology that a polity will enjoy constitutional stability only if it is not internally divided by a friend-enemy distinction does not entail that it must itself be a Schmittian political community, that is, that it must be constituted by a meta-legal friendenemy distinction, one that is drawn by reference to some exclusive marker of concrete identity, if it is to avoid internal division and be stable. The absence of internal division along friend-enemy lines would appear to suffice for the presence of social peace. This is not to say, I hasten to add, that there is no need for a political community to be bounded by some recognized criterion of belonging, or that it is unnecessary for members of the community to identify with a certain constitutional identity for the constitution to be stable. It is not even to deny, let it be duly noted, that a political community might face situations in which it has to be willing to defend itself against enemies in order to preserve its very existence. The point is simply that a motivationally efficacious sense of political identity could very well focus on the law of the constitution, as well as on the values that, under a principled interpretation, give it normative integrity - and not on a meta-constitutional concrete political identity that is merely expressed in, but not constituted by, the constitutional framework. 
Several examples of successful civic nationalisms, in particular the American example, seem to show that it is empirically possible for the members of a people to identify politically in a way that is essentially wedded to ongoing participation in an inclusive constitutional tradition, so that, in Hannah Arendt's words, 'the joint effort equalizes very effectively the differences in origin as well as in quality. ${ }^{, 61}$ The empirical claim that stable constitutional legality is possible only on the basis of sufficient relative homogeneity, we can surely conclude, is at the very least highly doubtful. And if production by Schmittian constituent power, or constitutional ownership based on a Schmittian notion of political identity, is not an indispensable empirical condition of democratic constitutional stability, the argument from stability/homogeneity loses most of its justificatory punch.

4.4 At any rate, it would not be difficult to find examples of polities in which attempts to introduce and entrench an exclusive constitutional identity based on some pre-political marker of identity have destabilized democratic constitutionality. The language of identity is all too easily exploited by populist political entrepreneurs bent on overcoming constitutional restraints. A defender of the argument from stability/homogeneity might reply that relative homogeneity is the only sufficient insurance of democracy against such entrepreneurship. But this retort does not fit very well with the fact that some of the most vivid current examples of democratic backsliding into authoritarianism unfold in rather homogeneous societies, such as Hungary and Poland. A hatred of the other that bolsters political authoritarianism need not focus on members of one's own society, it can be redirected towards real or imagined external threats, no matter how homogeneous the society in question. The reply also

\footnotetext{
${ }^{61}$ Hannah Arendt, On Revolution (Penguin 2006) 165. For a more recent reading of American constitutional history in this vein see Akheel Reed Amar, America's Constitution. A Biography (Random House 2006).
} 
overlooks that many polities simply do not enjoy the luxury of relative homogeneity. Circumstances often compel those who differ to live together, if catastrophic violence is to be avoided. In such cases, kicking the can down the road, as opposed to creating a constitution that embeds a clear decision for some concrete identity, is the most reasonable thing to do. ${ }^{62}$

4.5 Finally, the argument from stability/homogeneity is problematic because it seems to be committed to a normative valuation of the ideal of legality that stands in tension with the sovereigntist orientation of Böckenförde's conception of constituent power. If any possible outcome of a successful exercise of constituent power, even the peace of the graveyard, was to count as an instance of legality, it would be hard to see why the supposed relation between homogeneity and stable legality should, by itself, carry justificatory force. But once we enrich our notion of legality with normative principles of Rechtsstaatlichkeit, we will be driven towards the view that the legitimacy of constituent power is to be assessed in terms of whether the latter creates a constitution that is acceptable, in the light of an ideal of legality that is prior to and that binds constituent will.

\section{Böckenförde and the Argument from Identity}

5.1 There is, to belabor the obvious, a third, even more explicitly Schmittian way to understand the claim that production by the kind of constituent power described by Böckenförde legitimates a constitution, which I will call the argument from identity. I hesitate to attribute it to Böckenförde, but there are some passages in some of his writings that contain

\footnotetext{
${ }^{62}$ See Hanna Lerner, Making Constitutions in Deeply Divided Societies (CUP 2011).
} 
clear intimations of that view. ${ }^{63}$ The argument from identity is concerned to defend the claim that it is justifiable to deny full legal inclusion to residents or members of society who are perceived as existentially alien, for the simple reason that a homogeneous people is entitled to preserve its particular character. If people who are perceived as existentially alien are not to be regarded as part of the constituent community, it might be seen to be justifiable, by implication, to exclude them from the full enjoyment of the democratic rights of equal political participation that are grounded in true constitutional ownership, so as to prevent an excessive dilution of social homogeneity. Democratic equality, in Böckenförde's words, that here undoubtedly echo Schmitt's, is the equality of those whose shared concrete identity makes them belong to constituent community. It is not the equality of all human beings who are subject to or who are affected by the rule exercised by the democratic state. ${ }^{64}$

The legitimacy-claim defended by the theory of constituent power, according to the argument from identity, is not that production by constituent power serves to justify the constitution in the eyes of the potential critic or dissident. Rather, it is that the constitution is legitimate, in the eyes of the members of the constituent community, only as long as it is understood that it does not give a claim to equal standing to those who do not belong to the constituent community. A constitution that did not draw that distinction, or that was no longer understood as resting on it, could no longer be owned, no longer be seen as theirs, by those who are said to have produced it. This argument differs from the argument from stability/homogeneity in that it does not depend on the claim that there is an instrumental connection between homogeneity and the value stable constitutionality. It holds, rather, that exclusion would be justified even if inclusion posed no threat whatsoever to the stable functioning of legal and constitutional order.

\footnotetext{
${ }^{63}$ See for instance Böckenförde, 'Demokratie als Verfassungsprinzip' (n 54) 918.

${ }^{64}$ Compare ibid 915-919 and Schmitt, Constitutional Theory (n 28) 255-267.
} 
To paraphrase the key normative intuition: If a people is indeed truly sovereign, truly selfdetermining, it must claim and exercise the power to decide who belongs, and do so on the basis of whatever criterion of membership (and exclusion) it sees fit to treat as essential to its identity. If we (whoever we are) identify politically with a certain identity (whatever it may be) that excludes certain others (whoever they are), then who is to say that we are morally or legally bound to include those others? We determine how much difference to accept within our community. To hold that we are bound to some antecedent standard of inclusion that would force us to accept a measure of difference that we might find incommodious is to deny that we are sovereign, that we are free to come together on the basis of a shared identity and to express that identity in a public form of life. It is a claim that we will resist, if we truly are a political community, and that we are entitled to resist, unless the very existence of truly political communities - which, by definition, must be fully self-determining - is to be declared illegitimate.

5.2 I do not think that it is a promising endeavor to try to convince those who take the point of view of some political identity or other that they are morally mistaken to do so, though I believe they are. However, it is a rather straightforward exercise to show that the argument from identity must fail to substantiate the kind of criticism of the legitimacy of constitutional change that it is typically invoked to support.

The argument from identity claims that, say, the German Constitution was made by the German people, as identified by some pre-constitutional marker of political identity, and that its legitimacy therefore depends on its being understood as the Germans' constitution. The problem is that this idea will fail to provide a clear standard for deciding whose constitution, exactly, the constitution is. The reason for this is that it is politically contested, in Germany, 
as everywhere else, who ought to count as German. It is therefore also contested what it would mean to understand the German Constitution as the Germans' constitution. It follows that rhetorical invocations of constituent power will not help to decide what legal changes (within formal constitutional continuity) would or would not be compatible with constitutional ownership of the German Constitution by the German people, and thus be legitimate or illegitimate.

Schmitt's approach to constituent power tells us how such disputes are to be decided: Their resolution requires actual exercises of constituent power. Those who prevail in pulling off a successful exercise of constituent power (or sovereign dictatorship) are those who are entitled to speak for the people, and the people, or constituent power, are those who identify with the constitution so-produced. ${ }^{65}$ However, as we have already seen, the outcomes of actual exercises of constituent power cannot be predicted beforehand, especially where a society's own understanding of national identity is changing and contested. It therefore makes little sense, wherever understandings of constitutional identity have come to be contested, to raise a normative complaint to the effect that the existing constitution, as a system of constitutional laws, has come to be alienated from the true political identity of the constituent people that is supposed to undergird it. The complaint is valid, in a Schmittian context, only if those who raise it are capable to mobilize the political support to make their understanding of the nation's identity prevail as a matter of fact. If they do not have that capacity, and, for that reason, present their claim as though it was a claim of constitutional right, their presumption to speak in the name of the people must be specious, in the terms of their own understanding of constituent power.

\footnotetext{
${ }^{65}$ See Schmitt, Constitutional Theory (n 28) 126 and compare n 56.
} 
A Schmittian conception of constituent power does not, then, permit us to argue that the fact that the German Constitution was made by (or at least in) a community that still lived up to a certain concrete description of what it means to be German entails that the German Constitution must now continue to be regarded as the constitution of those who happen to fit that description and who think it ought to define the personal boundaries of the German nation. To make a normative claim of this sort is to fictionalize constituent power, to claim that there is some basic norm that determines that the understanding of political identity that, we assume, was present at the foundation must continue to bind future generations. Such a claim would strip constituent power of its character as a real power and an abiding presence, a power and presence that, as Böckenförde himself points out, ${ }^{66}$ can give continuing effectiveness to constitutional norms only because it is not held to have been exhausted in a one-time exercise of constitution-making in the past.

\section{Conclusion}

There may be other ways that have not been discussed here to explain the supposed legitimating force of a meta-legal and normatively unbridled constituent power. But I cannot think of any that strike me as promising and that are independent of the arguments discussed above. Böckenförde's strong theory of constituent power, I conclude, fails to offer a satisfactory account of constitutional legitimacy. In coming to this conclusion, I do not intend to reject the view that some more moderate theory of democratic constituent power might be needed to explain the legitimacy of constitutional law. It should be clear, though, that a cogent conception of constitutional legitimacy that appeals to constituent power cannot be developed on the basis of a strong, Schmittian notion of constituent power.

${ }^{66}$ Böckenförde, 'The Constituent Power of the People' (n 6) 175-176. 
The guiding intuition of strong theories of constituent power is that constituent power, in order to be truly and distinctively legitimating, must be unbound from existing positive constitutional law as well as from any moral limitation which claims to limit the popular sovereign. This demand for a constituent power freed from antecedent normativity is supported, as far as I can see, by all contemporary theorists of popular sovereignty who take their cues from Schmitt's and Böckenförde's approach. What has been argued here is that acceptance of this framing of the problem of constituent power carries a prohibitive price: If the popular sovereign is to be unbound from all antecedent normativity, then a theory of collective political identity rather like Schmitt's is required to answer the question who the people are. A Schmittian theory of political community, however, will inevitably sever the legitimating link between the will of the popular sovereign and the constituted political order - not because such a conception of the political is inherently essentialist or even racist (it is not), but rather because it lacks the conceptual resources to address those who question the constitution's legitimacy.

A theory of constituent power that holds that the popular sovereign must be unrestricted by existing law and context-transcendent morality permits of only two ways of being related to a political community and to its constitution: that of a friend, who does not need to be convinced that a constitution made by friends is justified, and that of a potentially hostile outsider over whom the constitution does not even claim to have normative authority. In this framework there simply is no conceptual space to make sense of the problems of legitimacy that arise in our ordinary experience of democratic citizenship. The latter, I take it, is characterized by an occasional (or not so occasional) dissatisfaction with political decisions taken by authorities who we do not always regard as our friends, but one that is accompanied by a principled willingness to defer to the outcomes of fair democratic procedures, protected by a democratic constitution, that provide equal voice to all those who are expected to obey. 
The democratic problem of constitutional legitimacy is to describe the conditions, which may include conditions that relate to a constitution's actual founding, under which the adoption of such an attitude of deference would be warranted, on the ground that one is faced with authentically democratic (constitutional) law. If constitutional theory is to provide an answer to the question of constitutional legitimacy, so understood, then it is well past time to leave the sovereigntist paradigm of constituent power behind. 